\title{
Water quality of the Atibaia river in the city of Paulínia/SP: evaluation of the Electrical Conductivity and Chloride variables
}

\author{
Qualidade da água do rio Atibaia no município de Paulínia/SP: \\ avaliação das variáveis Condutividade Elétrica e Cloretos

\section{Camila Pereira Montovani'(i), Cassiana Maria Reganhan Coneglian'®i, Elaine Cristina Catapani Poletti'}

\author{
'Universidade Estadual de Campinas (UNICAMP), São Paulo, SP, Brasil
}

\section{ABSTRACT}

The present study aimed to evaluate the characteristics that most influenced the water quality variability of the Atibaia river in the city of Paulínia/SP, the coordinates of the water collection point are given by $22^{\circ} 44^{\prime} 23^{\prime \prime}(S)$ and $47^{\circ} 07^{\prime} 40^{\prime \prime}(\mathrm{W})$, in the dry and rainy seasons, from 2006 to 2016 . The data used in this study come from the monitoring of parameters carried out in the spring by a research team, accompanied by periodic collections of surface water samples and analyzes laboratory tests. The parameters addressed included: precipitation, temperature, Hydrogenionic potential $(\mathrm{pH})$, turbidity, thermotolerant coliforms (Escherichia coli (E. coli)), dissolved oxygen (DO), biochemical oxygen demand $(B O D)$, chemical oxygen demand (COD), total nitrogen $\left(N_{\text {total }}\right)$, total phosphorus $\left(P_{\text {total }}\right)$, total dissolved solids (TDS), electrical conductivity (EC) and chlorides $\left(\mathrm{Cl}^{-}\right)$. Water quality was assessed using linear correlation analysis, using the Pearson Correlation coefficient ( $r$ ), and Multivariate Analysis, using Principal Component Analysis (PCA). The results obtained highlight the influence of EC, $\mathrm{Cl}^{-}, \mathrm{P}_{\text {total, }} \mathrm{DO}, \mathrm{pH}$, COD, turbidity and temperature on the water quality variability of the Atibaia river in the dry season, and $\mathrm{EC}, \mathrm{Cl}, \mathrm{N}_{\text {total, }} \mathrm{BOD}$ and $\mathrm{COD}$ in the rainy season. The presence of $\mathrm{EC}, \mathrm{Cl}^{-}$and $\mathrm{COD}$ in both periods indicates quality characteristics related to the mineralization of organic compounds present in the water and the eutrophication process.

Keywords: Atibaia river; PCA; Water quality; Pollution 


\section{RESUMO}

O presente estudo teve o objetivo de avaliar as características que mais influenciaram a variabilidade da qualidade das águas do rio Atibaia no município de Paulínia/SP, as coordenadas do ponto de coleta de

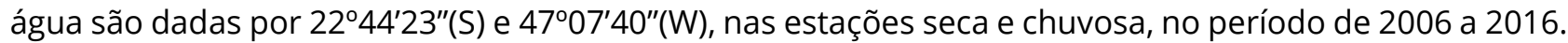
Os dados utilizados neste estudo são provenientes do monitoramento de parâmetros realizado no manancial por uma equipe de pesquisa, acompanhado de coletas periódicas de amostras de água superficial e análises laboratoriais. Os parâmetros abordados compreenderam: precipitação, temperatura, potencial Hidrogeniônico $(\mathrm{pH})$, turbidez, coliformes termotolerantes (Escherichia coli $(E$. coli)), oxigênio dissolvido (OD), demanda bioquímica de oxigênio (DBO), demanda química de oxigênio (DQO), nitrogênio total $\left(N_{\text {total }}\right)$, fósforo total $\left(P_{\text {total }}\right)$, sólidos totais dissolvidos $(S T D)$, condutividade elétrica (CE) e cloretos $\left(\mathrm{Cl}^{-}\right)$. A qualidade da água foi avaliada empregando-se análises de correlação linear, através do coeficiente de Correlação de Pearson ( $r$ ), e Análise Multivariada, mediante Análise de Componentes Principais (ACP). Os resultados obtidos ressaltam a influência de $\mathrm{CE}, \mathrm{Cl}$, $\mathrm{P}_{\text {total, }} \mathrm{DO}, \mathrm{pH}, \mathrm{DQO}$, turbidez e temperatura na variabilidade da qualidade das águas do rio Atibaia na estação seca, e $\mathrm{CE}, \mathrm{Cl}$, $\mathrm{N}_{\text {total, }} \mathrm{DBO}$ e DQO na estação chuvosa. A presença de $\mathrm{CE}, \mathrm{Cl}^{-}$e $\mathrm{DQO}$ em ambos os períodos indica características de qualidade relacionadas à mineralização de compostos orgânicos presente na água e ao processo de eutrofização.

Palavras-chave: Rio Atibaia; ACP; Qualidade da água; Poluição

\section{INTRODUCTION}

Water is an indispensable natural resource for the survival of animals, plants, and humans, however, its physical, chemical, and microbiological conditions have been largely impacted by anthropogenic activities, causing concerns and reflecting on the characteristics of rivers and water quality. Several factors affect surface freshwater, which makes monitoring the quality of water in water bodies essential, including accidents with spills of compounds, natural changes resulting from climate change, discharges of domestic and/or industrial effluents without appropriate treatment, among others (DURIGON et al., 2015; RAMOS et al., 2016; TAOUFIK et al., 2017).

Water quality monitoring is used to classify water bodies in classes that ensure multiple uses of water and, in the state of São Paulo, it is carried out by the São Paulo State Environmental Company (CETESB), a government agency responsible for the control, inspection, monitoring and licensing of pollutiongenerating activities, which also uses the Water Quality Index (WQI) to assess and classify the water quality of the springs. The WQI was adapted from the National Sanitation Foundation in the United States and nine parameters are analyzed: 
temperature, Hydrogenionic potential $(\mathrm{pH})$, dissolved oxygen (DO), biochemical oxygen demand (BOD), total dissolved solids (TDS), thermotolerant coliforms (Escherichia coli (E. coli)), total nitrogen $\left(\mathrm{N}_{\text {total }}\right)$, total phosphorus $\left(\mathrm{P}_{\text {total }}\right)$ and turbidity (LEITE et al., 2013, RAMOS et al., 2016).

Among important variables, precipitation, chemical oxygen demand (COD), electrical conductivity (EC), and chlorides $\left(\mathrm{Cl}^{-}\right)$do not configure the index, but are usually analyzed additionally to complement the quality determination analysis of the water body (LEITE et al., 2013, RAMOS et al., 2016).

The temperature reflects the degree of heating in the water bodies. This parameter is associated with the season and is affected by seasonality. It can be used as an indicator of thermal pollution (PIRATOBA et al., 2017). Through the presence of hydrogen ions $\left(\mathrm{H}^{+}\right)$the $\mathrm{pH}$ indicates whether the medium has an acidic or alkaline condition, being of utmost importance for the maintenance of aquatic life. The changes may have natural origins such as rock dissolution and photosynthesis, or anthropogenic via domestic and/or industrial effluents (GASPAROTTO, 2011).

Numerous aquatic organisms, including zooplankton and most fish species, do not tolerate low DO concentrations, as hypoxia conditions are created. DO is significant for several chemical reactions, reproduction, and diet of aquatic beings (DUBUC et al., 2017; NULL et al., 2017). The BOD indicates the amount of oxygen consumed by aerobic microorganisms to degrade the biodegradable organic matter while in the COD the oxygen consumption occurs via chemical oxidation. The closer the BOD value approaches the COD value, the more biodegradable the compounds present in the analyzed water will be (FRANCE, 2009).

TDS are particles smaller than $10^{-3} \mu \mathrm{m}$ that, after filtration, remain in solution. They are mainly composed of carbonates, bicarbonates, chlorides, sulfates, phosphates, calcium, magnesium and potassium nitrates (GASPAROTTO, 2011).

The group of thermotolerant coliforms comprises bacteria of the genus Escherichia which are considered biological indicators of fecal contamination since 
they are present in the gastrointestinal system of humans and warm-blooded animals (GASPAROTTO, 2011).

$N_{\text {total }}$ is an important element for aquatic life, but in excess, it causes damage to the environment. This parameter comprises the forms ammonia $\left(\mathrm{NH}_{3}{ }^{+}\right)$, nitrates $\left(\mathrm{NO}_{3}{ }^{-}\right)$, nitrites $\left(\mathrm{NO}_{2}{ }^{-}\right)$, and organic nitrogen. Its origin can be in domestic effluents, fertilizers, proteins, chlorophyll, and several other biological compounds (MARCONE, 2006). Total phosphorus, like $\mathrm{N}_{\text {total, }}$ is an essential element for plants and animals, however, it is an impurity in surface freshwaters when it is present in excess, causing eutrophication and fish mortality. It may come from natural causes, like the dissolution of soil compounds and the decomposition of organic matter, or anthropogenic, when it comes from domestic and/or industrial effluents, detergents, animal excrement, insecticides, and pesticides (SILVA JÚNIOR et al., 2017).

Turbidity indicates the concentrated and/or recent release of effluents into water bodies. In rainy periods, this variable can change due to erosion of the river banks. It is a significant parameter since it influences the amount of light that penetrates the aquatic environment (FRANCE, 2009; PIRATOBA et al., 2017). Precipitation directly influences the water quality of the water body, as the decrease results in a reduction of surface runoff and ion dilution (RIBEIRO et al., 2005; PIRATOBA et al., 2017).

The EC represents the ability of water to conduct electrical energy. According to França (2009), the EC "originates from the presence of salts dissolved in water in the form of electrolytically dissociated ions". The $\mathrm{Cl}^{-}$ion can be anthropogenic in origin, through domestic and/or industrial effluents, and geological, through leaching of rocks. It is extremely important for the aquatic ecosystem since it participates in physiological processes such as the exchange and transport of other ions to the intracellular and extracellular media. Its high concentrations in freshwater can provide a salty taste to the water, in addition to having properties under these conditions (PIRATOBA et al., 2017). 
Thus, the objective of this study was to identify the physical-chemical and/or microbiological characteristics with greater individual participation in the surface water quality of the Atibaia river and observe the effect of the sampling period (dry and rainy) using the linear correlation tools, through Pearson's Correlation coefficient ( $r$ ), and Multivariate Analysis, through Principal Component Analysis (PCA).

\section{MATERIAL AND METHODS}

\subsection{Study area}

The Atibaia river is formed by the confluence of the Atibainha and Cachoeira rivers, between the municipalities of Atibaia and Bom Jesus dos Perdões in the state of São Paulo, with springs located in the municipalities of Joanópolis, Piracaia and Nazaré Paulista (LOCATELLI, 2011; LEITE et al., 2013; CAMPOS, 2014; GONÇALVES, 2015; OLIVEIRA, 2016).

It is inserted in the Water Resources Management Unit 5 Piracicaba/Capivari/Jundiaí (UGRHI-5 - PCJ), in the Atibaia sub-basin, characterized as an industrial unit. The hydrographic sub-basin covers an area of $2,816.11 \mathrm{~km}^{2}$ and $397.56 \mathrm{~km}$ of perimeter. The river has an average flow of $31.38 \mathrm{~m}^{3} . \mathrm{s}^{-1}$ and $182.00 \mathrm{~km}$ in length (LOCATELLI, 2011; LEITE et al., 2013; CAMPOS, 2014, GONÇALVES, 2015, OLIVEIRA, 2016).

\subsection{Sample collection}

The data presented in this study come from monitoring and collecting samples of surface water from the Atibaia river in the period from 2006 to 2016.

The coordinates of the water collection point on the Atibaia river are given by $22^{\circ} 44^{\prime} 23^{\prime \prime}(S)$ and $47^{\circ} 07^{\prime} 40^{\prime \prime}(\mathrm{W}), 800 \mathrm{~m}$ from the wastewater discharge point of a company in the city of Paulínia/SP (Figure 1). 
Figure 1 - Location of the surface water sampling point on the Atibaia river

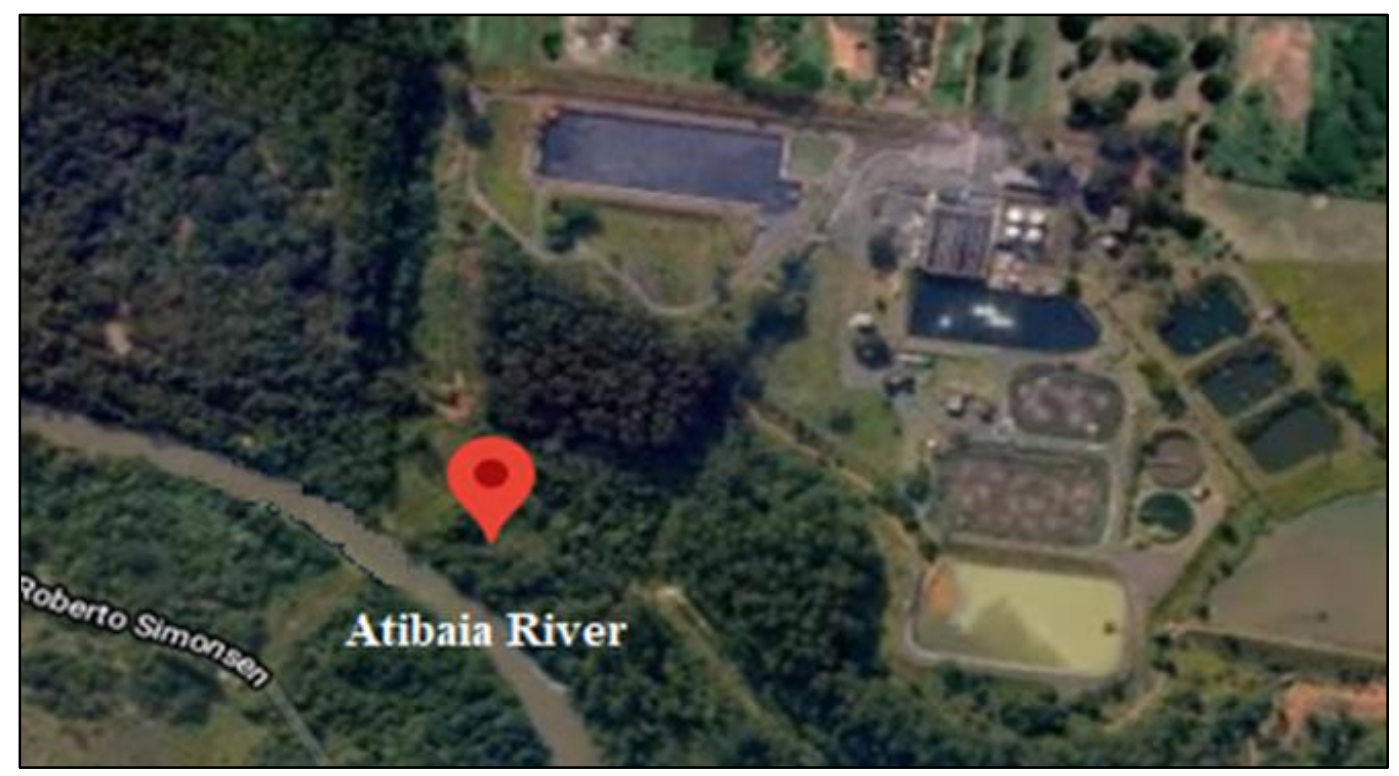

Source: GOOGLE MAPS, 2020

In total there are 183 samples of surface water and 2,196 analyzes following the methodologies indicated in the Standard Methods for the Examination of Water and Wastewater, 20th edition, with the results made available for this study (APHA, 1995).

The collected samples were analyzed for the variables recommended by CETESB, through the WQI, plus three other variables considered ecologically important, making a total of twelve monitoring variables: DO, BOD, COD, E. coli, pH, $\mathrm{Cl}^{-}, \mathrm{EC}$, temperature, turbidity, TDS, $\mathrm{N}_{\text {total }}$ and $\mathrm{P}_{\text {total }}$.

Precipitation data were obtained from reports issued by the Agrometeorology Information Center (CIIAGRO). Because there are no records of precipitation over the entire period $(2011,2012,2013,2014$, and from February 2015 to January 2016) for the municipality of Paulínia/SP, data from the municipality of Campinas/SP were used to complement the information board.

\subsection{Data analysis}

The results of the analysis of these variables generated a large, important and complex set of data that was analyzed using statistical tools of correlation via 
the Pearson Correlation coefficient $(r)$ and Multivariate Statistics via Principal Component Analysis (PCA) (FINKLER et al., 2020; TAOUFIK et al., 2017).

Such analysis techniques were applied in order to favor the interpretation of the data and the identification of the variables that most contributed to the state of degradation of the water quality of the Atibaia river in the aforementioned period. Once the main variables were identified, it was possible to eliminate those that least contributed to water pollution.

These techniques can also be applied to identify sources of pollution, to manage water resources, and to reduce the time and costs of analysis (TAOUFIK et al., 2017).

Then two large data matrices were obtained and the data were divided between the dry season (autumn and winter) and the rainy season (spring and summer). Each matrix was composed of thirteen columns, represented by the analyzed variables.

For tabulation, data treatment, and calculation of Pearson Correlation, the software Calc, an electronic spreadsheet of the package Libre Office version 6.3.3.2, was used. Pearson's correlation coefficient is an $r$ value such that $r<|1|$ that assesses the correlation between two variables, regardless of the unit of measurement. This coefficient can be positive or negative. The positive linear correlation indicates that the variables are directly proportional, while the negative linear correlation indicates that the variables are inversely proportional to each other (MAIA et al., 2019).

The criteria used in this study to classify Pearson's Correlation coefficient followed those used by Callegari-Jacques (2003), weak correlation for $r$ between 0.00 to 0.30 , moderate for $r$ between 0.30 to 0.60 , strong for $r$ between 0.60 and 0.90 , and very strong for $r$ between 0.90 to 1.00 .

Regarding the study of multivariate correlation, PCA analysis was used, which allows variables to be analyzed simultaneously. In this analysis, the dimension of the original data set, with possibly correlated variables, is reduced, giving rise to a 
new data set with unrelated variables called principal components (PC) without considerable loss of information (FINKLER et al., 2016).

This analysis was performed in a computational environment using the Palaeontological Statistics (PaSt) version 3.24 software, where we chose to use the correlation matrix to eliminate the effects of scale and units since the variables have different units of measurement (FRANCE, 2009 ; BERTOSSI et al., 2013; MAIA et al., 2019).

For the selection of the number of main components, the Kaiser Criterion, or Latent Root Criterion, was used, where only the PCs with an eigenvalue $\left(\lambda_{i}\right)$ greater than one (HONGYU et al., 2016) are considered.

Resolutions of the National Environment Council (CONAMA) $n^{\circ} 357 / 2005$ (BRASIL, 2005) and CONAMA $n^{\circ} 430 / 2011$ (BRASIL, 2011) were used to verify that the results were within the limits established for surface freshwater framed in the Class 2, given the role of the preponderant uses, current and future, and the level of water quality of the Atibaia river.

\section{RESULTS AND DISCUSSION}

The limits established by CONAMA $n^{\circ} 357 / 2005$ and CONAMA n ${ }^{\circ} 430 / 2011$, minimum, maximum, average, and standard deviation of the physical-chemical and microbiological analyzes of the waters of the Atibaia river in the dry and rainy seasons are shown in Table 1.

According to the results in Table 1, it appears that the parameters $\mathrm{Cl}^{-}, \mathrm{pH}^{-}$ and temperature were fully within the maximum limits established in legislation, CONAMA $n^{\circ} 357 / 2005$ and CONAMA n $430 / 2011$. $\mathrm{Cl}^{-}$ranged from 3.45 to 110.74 mg. $\mathrm{L}^{-1}$ in the dry season and from 0 to $164.71 \mathrm{mg} \cdot \mathrm{L}^{-1}$ in the rainy season and the resolution establishes a limit $<250 \mathrm{mg} \cdot \mathrm{L}^{-1}$. The $\mathrm{pH}$ varied between 7.06 and 8.93 in the dry season and between 6.84 and 8.03 in the rainy season, being within the expected limits of 6.00 to 9.00 . The temperature fluctuated between 15 and $30^{\circ} \mathrm{C}$ 
and between 17 and $30^{\circ} \mathrm{C}$ in the dry and rainy seasons, respectively, remaining < $40^{\circ} \mathrm{C}$

Table 1 - Limits, minimum and maximum values verified in the collections, average and standard deviation of the values obtained in the physical-chemical and microbiological analyzes of the waters of the Atibaia river in the dry and rainy seasons, period 2006 to 2016

\begin{tabular}{|c|c|c|c|c|c|c|c|}
\hline & \multirow[b]{2}{*}{ Lim it* } & \multicolumn{3}{|c|}{ Dry season } & \multicolumn{3}{|c|}{ Rainy season } \\
\hline & & Minimum & Maximum & Average $\pm S D$ & Minimum & Maximum & Average \pm SD \\
\hline EC & $<100.00 \mu \mathrm{S} . \mathrm{cm}^{-1}$ & 93.00 & $1,087.00$ & $342.05 \pm 192.40$ & 76.40 & $1,364.00$ & $293.15 \pm 249.92$ \\
\hline $\mathrm{Cl}^{-}$ & $<250.00 \mathrm{mg} \cdot \mathrm{L}^{-1}$ & 3.45 & 110.74 & $27.79 \pm 19.54$ & $\star \star$ & 164.71 & $27.54 \pm 29.67$ \\
\hline TDS & $<500.00 \mathrm{mg} \cdot \mathrm{L}^{-1}$ & 21.79 & $1,346.00$ & $310.61 \pm 211.34$ & 59.20 & 770.00 & $275.54 \pm 130.60$ \\
\hline $\mathrm{pH}$ & 6.00 a 9.00 & 7.06 & 8.93 & $7.56 \pm 0.28$ & 6.84 & 8.03 & $7.55 \pm 0.25$ \\
\hline BOD & $<5.00 \mathrm{mg} \cdot \mathrm{L}^{-1}$ & 2.00 & 32.90 & $12.92 \pm 6.18$ & 1.10 & 61.00 & $13.63 \pm 7.39$ \\
\hline COD & - & 2.16 & 75.44 & $18.88 \pm 11.91$ & 1.68 & 64.96 & $19.64 \pm 8.86$ \\
\hline DO & $>5.00 \mathrm{mg} \cdot \mathrm{L}^{-1}$ & 0.73 & 9.59 & $6.23 \pm 1.97$ & 0.34 & 9.55 & $5.14 \pm 2.22$ \\
\hline $\mathrm{N}_{\text {total }}$ & $<0.10 \mathrm{mg} \cdot \mathrm{L}^{-1}$ & 0.35 & 36.93 & $8.18 \pm 7.72$ & ** & 68.22 & $8.64 \pm 11.91$ \\
\hline $\mathbf{P}_{\text {total }}$ & $<0.10 \mathrm{mg} \cdot \mathrm{L}^{-1}$ & 0.01 & 1.35 & $0.29 \pm 0.30$ & 0.01 & 0.97 & $0.19 \pm 0.16$ \\
\hline Turbidity & $<100.00$ UNT & 5.47 & 132.00 & $31.94 \pm 26.63$ & 6.00 & 263.00 & $56.96 \pm 56.78$ \\
\hline Precipitation & - & $\star \star$ & 218.20 & $54.02 \pm 52.20$ & 6.70 & 438.00 & $159.69 \pm 100.00$ \\
\hline Temperature & $<40^{\circ} \mathrm{C}$ & 15.00 & 30.00 & $21.90 \pm 3.46$ & 17.00 & 30.00 & $23.14 \pm 2.76$ \\
\hline E. coli & $\begin{array}{l}<1,000.00 \\
\operatorname{NMP}(100 \mathrm{~mL})^{-1}\end{array}$ & 200.00 & $900,000.00$ & $\begin{array}{l}50,252.97 \pm \\
142,362.15\end{array}$ & 200.00 & $900,000.00$ & $\begin{array}{l}35,573.62 \pm \\
113,585.93\end{array}$ \\
\hline
\end{tabular}

In were: * Limits established by CONAMA $n^{\circ} 357 / 2005$ and CONAMA $n^{\circ} 430 / 2011$; ** Result below the detection limit of the analysis method performed.

The average concentrations of the variables: EC, TDS, BOD, DO, $\mathrm{N}_{\text {total, }} \mathrm{P}_{\text {total, }}$ turbidity, and $E$. coli were higher than those recommended by CONAMA Resolution $\mathrm{n}^{\circ} 357 / 2005$, in both periods. For the EC, the mean value \pm the standard deviation evaluated was $342.05 \pm 192.40 \mu \mathrm{S} . \mathrm{cm}^{-1}$ in the dry season and $293.15 \pm 249.92$ $\mu \mathrm{S} . \mathrm{cm}^{-1}$ in the rainy season, the maximum limit being established $<100.00 \mu \mathrm{S}^{\mathrm{cm}^{-}}$ 1 . For TDS the mean value \pm the standard deviation evaluated was $310.61 \pm 211.34$ $\mathrm{mg} \cdot \mathrm{L}^{-1}$ in the dry season and $275.54 \pm 130.60 \mathrm{mg} \cdot \mathrm{L}^{-1}$ in the rainy season, with the maximum limit established $<500.00 \mathrm{mg} \cdot \mathrm{L}^{-1}$. The BOD presented mean \pm the standard deviation of $12.92 \pm 6.18 \mathrm{mg} \cdot \mathrm{L}^{-1}$ in the dry season and $13.63 \pm 7.39 \mathrm{mg} . \mathrm{L}^{-}$ 1 in the rainy season, the limit being set to values $<5.00 \mathrm{mg}$. $\mathrm{L}^{-1}$. The DO evaluated was $6.23 \pm 1.97 \mathrm{mg} . \mathrm{L}^{-1}$ in the dry season and $5.14 \pm 2.22 \mathrm{mg} . \mathrm{L}^{-1}$ in the rainy season and the one indicated by the Resolution is $>5.00 \mathrm{mg} \cdot \mathrm{L}^{-1}$. The $\mathrm{N}_{\text {total }}$ evaluated was $8.18 \pm 7.72 \mathrm{mg} \cdot \mathrm{L}^{-1}$ in the dry season and $8.64 \pm 11.91 \mathrm{mg} \cdot \mathrm{L}^{-1}$ in the rainy season and that indicated by the Resolution is $<0.10 \mathrm{mg} \cdot \mathrm{L}^{-1}$. The Ptotal obtained in the samples 
was $0.29 \pm 0.30 \mathrm{mg} \cdot \mathrm{L}^{-1}$ and $0.19 \pm 0.16 \mathrm{mg} \cdot \mathrm{L}^{-1}$ in the dry and rainy seasons, respectively, with the indication $<0.10 \mathrm{mg}^{-1} \mathrm{~L}^{-1}$. Escherichia coli had an average concentration of $50,252.97 \pm 142,362.15 \mathrm{NMP}(100 \mathrm{~mL})^{-1}$ in the dry season and $35,573.62 \pm 113,585.93 \mathrm{NMP}(100 \mathrm{~mL})^{-1}$ in the rainy season and the Resolution establishes < 1,000.00 NMP(100 mL)-1 (BRASIL, 2005).

The correlations between the thirteen variables in the dry season and in the rainy season were determined using Pearson Correlation matrix and are presented, respectively, in Tables 2 and 3.

According to the results presented in Table 2, it is observed, regarding the data in the dry season, that the variables: $\mathrm{EC}$ and $\mathrm{Cl}^{-}(r=0.88), \mathrm{EC}$ and $\mathrm{P}_{\text {total }}(r=$ $0.61)$, and EC and DO ( $r=-0.62)$ were strongly correlated.

The parameters $\mathrm{Cl}^{-}$and $P_{\text {total }}(r=0.59), \mathrm{Cl}^{-}$and $\mathrm{DO}(r=-0.54), \mathrm{Cl}^{-}$and precipitation $(r=-0.33)$, and DO and $P_{\text {total }}(r=-0,48)$ are moderately correlated.

The results presented in the rainy season (Table 3 ), indicate that the highly correlated variables are: $\mathrm{EC}$ and $\mathrm{Cl}^{-}(r=0.82), \mathrm{EC}$ and $\mathrm{N}_{\text {total }}(r=0.69)$, and $\mathrm{Cl}^{-}$and $N_{\text {total }}(r=0.71)$.

In the rainy season, the variables EC and BOD $(r=0.33), E C$ and $P_{\text {total }}(r=0.31)$, $\mathrm{Cl}^{-}$and BOD $(r=0.37)$, TDS and BOD $(r=0.32), \mathrm{BOD}$ and COD $(r=0.53), \mathrm{N}_{\text {total }}$ and $P_{\text {total }}(r=0.36)$, turbidity and precipitation $(r=0.42)$, EC and DO $(r=-0.35)$, EC and turbidity $(r=-0.40)$, and $N_{\text {total }}$ and turbidity $(r=-0.35)$.

Based on the Correlation matrix between the variables, the data were submitted to the analysis of main components, PCA, the same being normalized due to the variety of units of measurement between the parameters. The outliers resulting from the analyzes were not discarded because the information had been obtained from a database, which does not allow to identify the reasons for the divergences.

Based on the results obtained for the main components, their respective eigenvalues $\left(\lambda_{i}\right)$ and percentages of variance (\% PCV) (Table 4), it has nine (39.52\%) of the thirteen main components, PCs, presented eigenvalue less than one in the 
dry season while, in the rainy season, eight (29.58\%) had an eigenvalue of less than one.

Of the thirteen PC generated, PC 1 and 2 were selected because they presented variance (eigenvalue) greater than one. The composition of each PC varies according to the weighting coefficient (eigenvector) assigned to each variable (Table 5).

From the results of the PCA, it was observed that a model with two PC was adequate to represent the characteristics of the variables analyzed in the waters and explain $40.38 \%$ of the total variance in the dry season and $40.14 \%$ in the rainy season (Table 6).

Table 2 - Pearson's Correlation Matrix - dry season

\begin{tabular}{|c|c|c|c|c|c|c|c|c|c|c|c|c|c|}
\hline & $\mathrm{EC}$ & $\mathrm{Cl}^{-}$ & TDS & $\mathrm{pH}$ & $B O D$ & COD & DO & $\mathrm{N}_{\text {tots }}$ & $P_{\text {total }}$ & Turbidity & Precipitation & Temperature & E. colli \\
\hline EC & 1.00 & & & & & & & & & & & & \\
\hline $\mathrm{Cl}$ & 0.88 & 1.00 & & & & & & & & & & & \\
\hline TDS & 0.18 & 0.07 & 1.00 & & & & & & & & & & \\
\hline pH & -0.15 & -0.21 & 0.13 & 1.00 & & & & & & & & & \\
\hline BOD & 0.27 & 0.17 & -0.01 & -0.11 & 1.00 & & & & & & & & \\
\hline COD & 0.14 & 0.07 & 0.05 & 0.15 & 0.28 & 1.00 & & & & & & & \\
\hline DO & -0.62 & -0.54 & -0.12 & 0.02 & -0.22 & -0.15 & 1.00 & & & & & & \\
\hline $\mathrm{N}_{\text {total }}$ & 0.26 & 0.28 & -0.20 & -0.25 & 0.06 & -0.09 & -0.05 & 1.00 & & & & & \\
\hline$P_{\text {total }}$ & 0.61 & 0.59 & 0.27 & -0.12 & 0.07 & -0.07 & -0.48 & 0.09 & 1.00 & & & & \\
\hline Turbidity & -0.21 & -0.22 & 0.09 & 0.19 & 0.18 & 0.12 & 0.21 & -0.23 & -0.18 & 1.00 & & & \\
\hline Precipitation & .0 .29 & -0.33 & -0.08 & -0.04 & 0.04 & 0.01 & 0.28 & -0.07 & .0 .23 & 0.15 & 1.00 & & \\
\hline Temperature & -0.01 & -0.01 & -0.09 & -0.30 & 0.09 & -0.13 & -0.07 & 0.08 & 0.06 & -0.28 & 0.23 & 1.00 & \\
\hline E. coll & .0 .14 & .0 .20 & -0.04 & 0.17 & 0.09 & 0.17 & 0.03 & -0.09 & .0 .13 & 0.23 & 0.25 & -0.11 & 1.00 \\
\hline
\end{tabular}

Table 3 - Pearson's Correlation Matrix - rainy season

\begin{tabular}{|c|c|c|c|c|c|c|c|c|c|c|c|c|c|}
\hline & $E C$ & $\mathrm{Cl}^{2}$ & TDS & $\mathrm{pH}$ & $B O D$ & COD & DO & $N_{t \alpha d x}$ & $P_{\text {total }}$ & Turbidity & Precipitation & Temperature & E. colli \\
\hline EC & 1.00 & & & & & & & & & & & & \\
\hline $\mathrm{Cl}^{\circ}$ & 0.82 & 1.00 & & & & & & & & & & & \\
\hline TDS & -0.01 & 0.01 & 1.00 & & & & & & & & & & \\
\hline pH & 0.07 & 0.02 & -0.02 & 1.00 & & & & & & & & & \\
\hline BOD & 0.33 & 0.37 & 0.32 & 0.03 & 1.00 & & & & & & & & \\
\hline$C O D$ & -0.15 & -0.04 & 0.28 & 0.11 & 0.53 & 1.00 & & & & & & & \\
\hline DO & -0.35 & .0 .28 & 0.06 & -0.18 & 0.08 & 0.18 & 1.00 & & & & & & \\
\hline$N_{\text {total }}$ & 0.69 & 0.71 & -0.02 & .0 .06 & 0.27 & .0 .07 & .0 .09 & 1.00 & & & & & \\
\hline$P_{\text {total }}$ & 0.31 & 0.26 & 0.23 & -0.19 & 0.08 & -0.01 & 0.01 & 0.36 & 1.00 & & & & \\
\hline Turbidity & -0.40 & -0.28 & 0.17 & -0.10 & -0.03 & 0.16 & 0.10 & -0.35 & .0 .09 & 1.00 & & & \\
\hline Precipitation & .0 .24 & .0 .22 & .0 .04 & -0.08 & -0.08 & 0.22 & 0.04 & .0 .29 & 0.08 & 0.42 & 1.00 & & \\
\hline Temperature & 0.17 & 0.20 & -0.11 & -0.22 & 0.08 & -0.15 & 0.11 & 0.22 & $=0.07$ & -0.25 & -0.12 & 1.00 & \\
\hline E. coll & -0.07 & -0.05 & -0.07 & 0.16 & 0.14 & 0.06 & 0.17 & -0.10 & -0.21 & .0 .06 & 0.19 & 0.01 & 1.00 \\
\hline
\end{tabular}


Table 4 - PC, $\lambda_{i}$, \% VCP e accumulated VCP\%

\begin{tabular}{lcccccc}
\hline & \multicolumn{3}{c}{ Dry season } & \multicolumn{3}{c}{ Rainy season } \\
\cline { 2 - 7 } & $\boldsymbol{\lambda}_{\mathbf{i}}$ & \% VCP & $\begin{array}{c}\text { Accumulated \% } \\
\text { VCP }\end{array}$ & $\boldsymbol{\lambda}_{\mathbf{i}}$ & \% VCP & Accumulated \% VCP \\
\hline 1 & 3.38 & 25.98 & 25.98 & 3.28 & 25.22 & 25.22 \\
2 & 1.87 & 14.41 & 40.38 & 1.94 & 14.92 & 40.14 \\
3 & 1.47 & 11.32 & 51.70 & 1.46 & 11.26 & 51.40 \\
4 & 1.14 & 8.77 & 60.48 & 1.38 & 10.58 & 61.98 \\
5 & 0.92 & 7.08 & 67.55 & 1.10 & 8.44 & 70.42 \\
6 & 0.88 & 6.81 & 74.36 & 0.88 & 6.76 & 77.18 \\
7 & 0.73 & 5.61 & 79.96 & 0.72 & 5.56 & 82.73 \\
8 & 0.64 & 4.91 & 84.88 & 0.64 & 4.92 & 87.65 \\
9 & 0.61 & 4.66 & 89.53 & 0.57 & 4.40 & 92.05 \\
10 & 0.47 & 3.61 & 93.14 & 0.34 & 2.65 & 94.70 \\
11 & 0.42 & 3.20 & 96.34 & 0.31 & 2.38 & 97.09 \\
12 & 0.38 & 2.90 & 99.24 & 0.23 & 1.79 & 98.88 \\
13 & 0.10 & 0.76 & 100.00 & 0.15 & 1.12 & 100.00 \\
\hline
\end{tabular}

Table 5 - Weighting coefficient of each PC

\begin{tabular}{lcccc}
\hline & \multicolumn{2}{c}{ Dry season } & \multicolumn{2}{c}{ Rainy season } \\
\cline { 2 - 5 } & PC1 & PC2 & PC1 \\
\hline EC & 0.49 & 0.12 & 0.50 & 0.02 \\
$\mathrm{Cl}^{-}$ & 0.48 & 0.04 & 0.48 & 0.09 \\
$\mathrm{TDS}$ & 0.10 & 0.29 & 0.01 & 0.45 \\
$\mathrm{PH}$ & -0.14 & 0.41 & 0.00 & 0.01 \\
$\mathrm{BOD}$ & 0.13 & 0.20 & 0.20 & 0.54 \\
$\mathrm{COD}$ & 0.03 & 0.40 & -0.08 & 0.57 \\
DO & -0.39 & -0.17 & -0.17 & 0.18 \\
$\mathrm{~N}_{\text {total }}$ & 0.18 & -0.30 & 0.47 & 0.05 \\
$\mathrm{P}_{\text {total }}$ & 0.40 & 0.06 & 0.21 & 0.18 \\
Turbidity & -0.20 & 0.39 & -0.30 & 0.23 \\
Precipitation & -0.24 & -0.09 & -0.24 & 0.19 \\
Temperature & 0.05 & -0.40 & 0.17 & -0.15 \\
E.coli & -0.15 & 0.29 & -0.08 & 0.09 \\
\hline
\end{tabular}


Table 6 - Variables with greater weight in the definition of PCs

\begin{tabular}{lccc}
\hline & PC & Variables Dry season & Variables Rainy season \\
\hline $\begin{array}{l}\text { PC with } \\
\text { high }\end{array}$ & 1 & $\mathrm{EC}(+), \mathrm{Cl}^{-}(+), \mathrm{DO}(-)$, Ptotal $(+)$ & $\mathrm{EC}(+), \mathrm{Cl}^{-}(+), \mathrm{N}_{\text {total }}(+)$ \\
variance & 2 & $\mathrm{pH}(+), \mathrm{COD}(+)$, turbidity $(+)$, & $\mathrm{BOD}(+), \mathrm{COD}(+), \mathrm{TDS}(+)$ \\
\hline
\end{tabular}

The information obtained for PC 1 and 2 is presented graphically taking into account the weights of the variables in these components. Figures 2 and 3 show the PCA graph via biplot with the formation of the mentioned groups of variables for the dry and rainy seasons, respectively.

According to Figure 2, dry season, in $\mathrm{PC} 1$, it is noted that the variables $\mathrm{EC}, \mathrm{Cl}^{-}$ and $\mathrm{P}_{\text {total }}$ are positively correlated with each other, while DO is negatively correlated with these variables. In component 2, COD, turbidity, and pH are the most positively correlated; temperature is negatively correlated with $\mathrm{pH}$ and turbidity.

Figure 2 - PCA chart via biplot - dry season

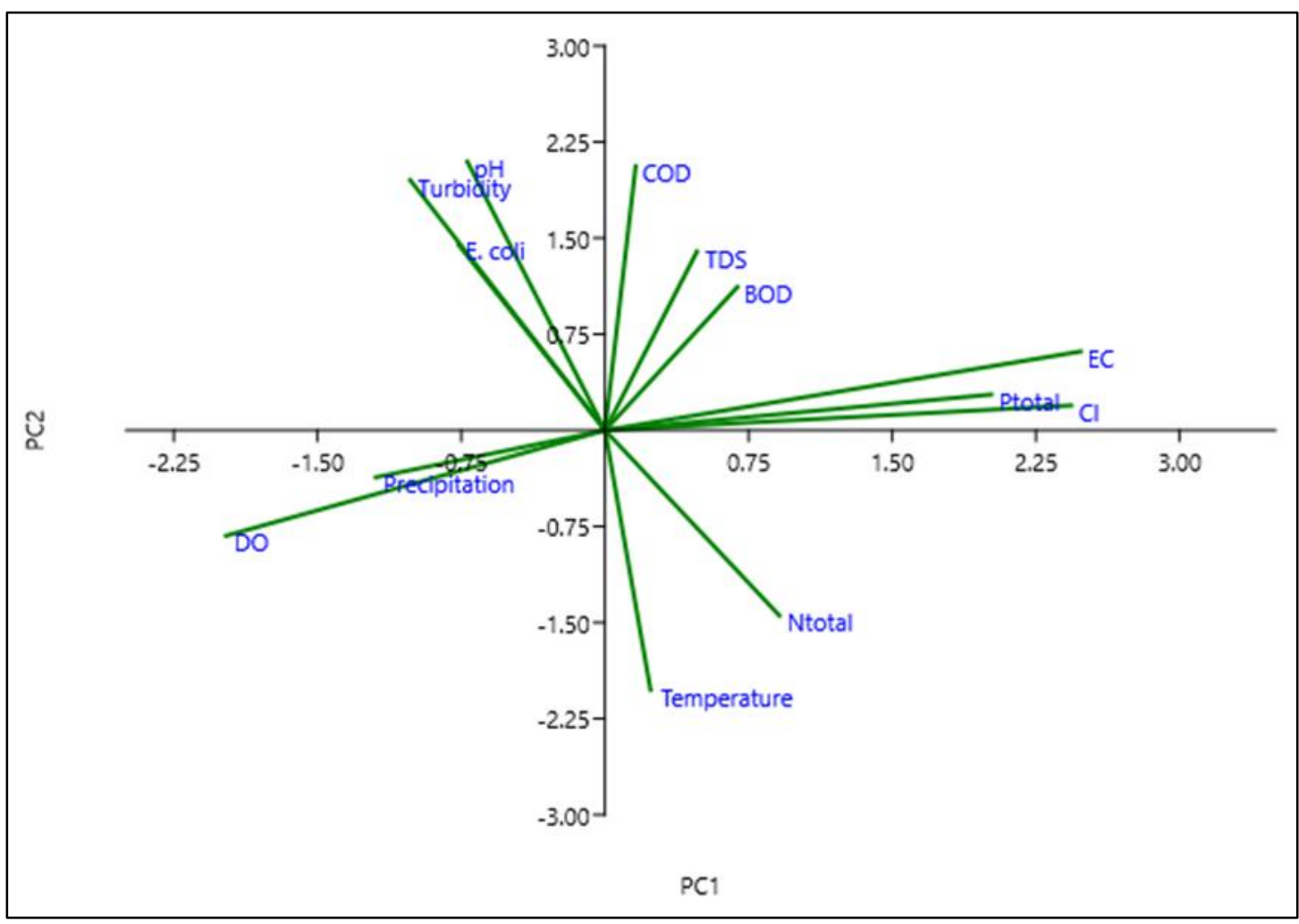

Source: Authors (2020) 
In PC1, the rainy season (Figure 3), it is noted that the variables $\mathrm{EC}, \mathrm{Cl}^{-}$and $\mathrm{N}_{\text {total }}$ are positively correlated with each other. In component 2, the variables positively correlated with each other are COD, BOD, and TDS. The other variables did not present a significant factor load.

The selected variables, $\mathrm{EC}, \mathrm{Cl}^{-}, \mathrm{P}_{\text {total }}, \mathrm{DO}, \mathrm{pH}, \mathrm{COD}$, turbidity and temperature in the dry season, and $\mathrm{EC}, \mathrm{Cl}^{-}, \mathrm{N}_{\text {total }}, \mathrm{BOD}, \mathrm{COD}$, and TDS in the rainy season, represent contributions from different sources of pollution such as organic pollution and nutrients, industrial and/or domestic effluents, as well as climatic conditions.

For PC1 there was a positive correlation for $\mathrm{EC}, \mathrm{Cl}^{-}$and $\mathrm{P}$ total, in the dry season, and $\mathrm{EC}, \mathrm{Cl}^{-}$and $\mathrm{N}_{\text {total, }}$ in the rainy season. These parameters are related, as these variables influence each other. EC can be altered by the presence of inorganic solids dissolved in water such as chloride, nitrate, and phosphate anions (GASPAROTTO, 2011; KIMURA, 2014; EPA, 2017).

According to Piratoba et al. (2017), there is a direct relationship between EC and ions, as high ion concentrations indicate high EC values, indicating the presence of salts in the water body (VASCONCELOS SEGUNDO et al., 2016).

Figure 3 - PCA graph via biplot - rainy season

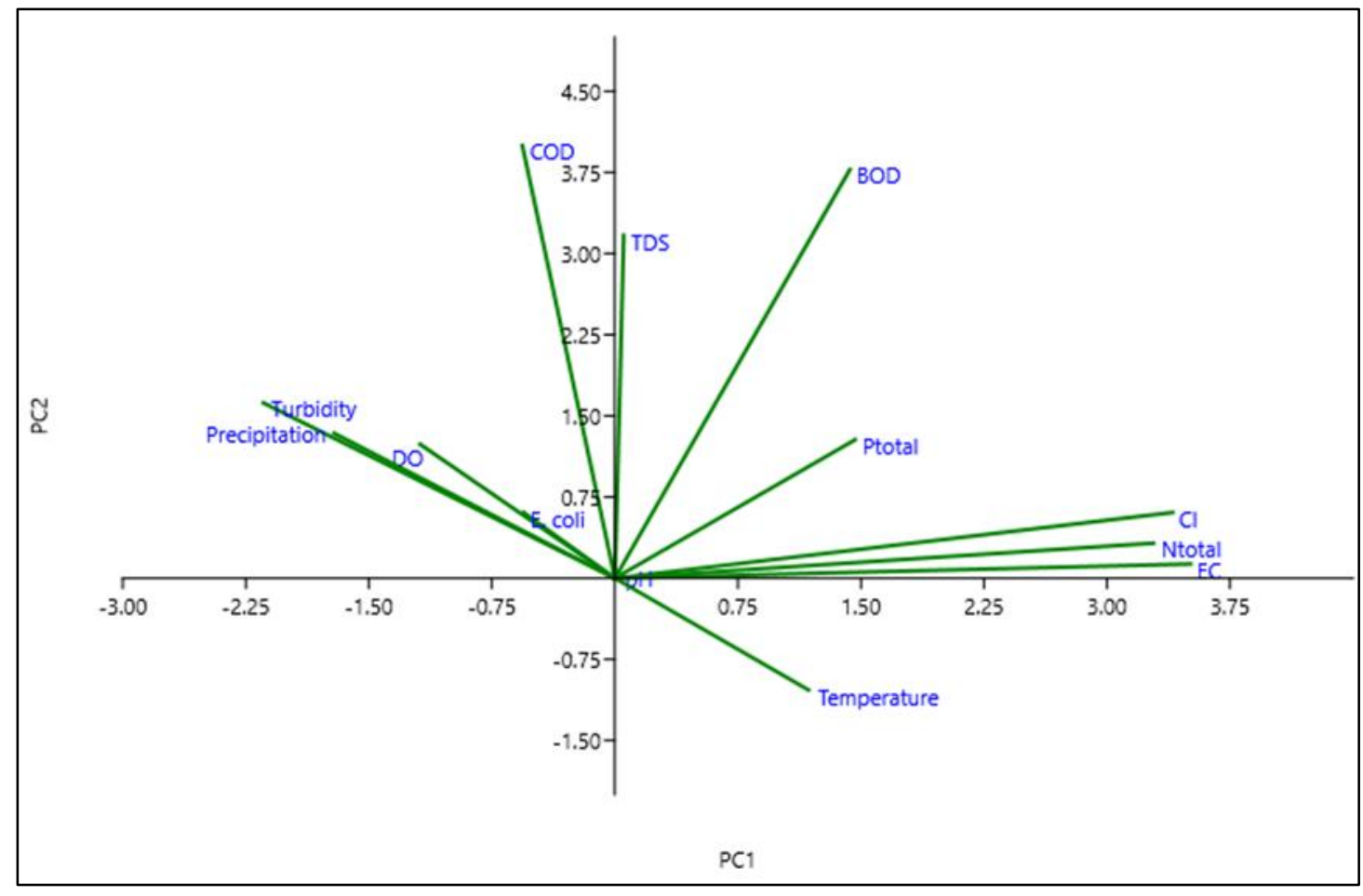

Source: Authors (2020) 
The negative correlation of $\mathrm{DO}$, in the dry season, concerning $\mathrm{EC}, \mathrm{Cl}^{-}$and $\mathrm{P}_{\text {total }}$ may indicate eutrophication since excess phosphorus provides such a scenario and oxygen depletion (LEITE et al., 2013; EPA, 2017).

According to Vasconcelos Segundo et al. (2016), the inverse correlation between DO and EC occurs due to the use of DO in the decomposition of organic matter present in the water body, leading to an increase in ions and, consequently, an increase in EC values.

For $\mathrm{PC2}, \mathrm{pH}, \mathrm{COD}$, turbidity and temperature, in the dry season, and $\mathrm{BOD}$, COD, and TDS, in the rainy season, showed a significant correlation between them.

It is observed that in periods of low temperature, due to the dry season being present in the coldest months of the year, there is a high $\mathrm{pH}$ due to the increased solubility of gases in water (MARCONE, 2006).

The increase in $\mathrm{pH}$ can be caused by the intense rate of photosynthesis, characteristic of the eutrophication process, promoting an increase in turbidity and COD (MARCONE, 2006; KIMURA, 2014; OLIVEIRA, 2016).

In times of lower precipitation, the highest ion concentrations are observed, including $\mathrm{Cl}^{-}$(RIBEIRO et al., 2005; PIRATOBA et al., 2017).

In the rainy season, it is observed that the variables COD, BOD, and TDS have a positive correlation and a high weighting coefficient. The existing correlation between $B O D$ and $C O D$, parameters that point to the degradation of organic matter, indicates a eutrophic environment caused by dumping of domestic and/or industrial organic origin interfering in aquatic life (FRANCE, 2009; GARDIMAN JUNIOR, 2015).

The climatic conditions of the rainy season influence the TDS parameter. This parameter indicates recent organic contamination in rivers by domestic and/or industrial effluents, which affects the organoleptic quality of the water (FRANCE, 2009; GASPAROTTO, 2011; LEITE et al., 2013).

Even with factorial load with low significance and weak correlation, it is observed that, in the rainy season, occurring in the hottest months of the year, the 
temperature is opposite to the DO, due to a negative correlation between these variables since the warmer water retains less oxygen (TAOUFIK et al., 2017).

The correlation between TDS and $P_{\text {total }}$ also presents factor load with low significance and weak correlation in the rainy season, however, TDS is associated with phosphorus transport (LEITE et al., 2013)

The study shows that in both periods there are parameters in common, such as $\mathrm{EC}, \mathrm{Cl}^{-}$and $\mathrm{COD}$, among the variables surveyed, being necessary to consider the variation of the studied period, rainy and dry, to determine the water quality, its monitoring and management.

\section{CONCLUSION}

The analysis of the data performed indicates the water quality of the Atibaia river, in the stretch of the municipality of Paulínia/SP, a populous area and of considerable economic relevance in the state of São Paulo. According to the results, subdivided into dry and rainy periods, the surface freshwaters of this water body suffer from the various impacts of anthropic origin, due to the contribution of domestic and/or industrial effluents that cause the degradation of the environment.

Among the thirteen parameters evaluated, only $\mathrm{Cl}^{-}, \mathrm{pH}$, and temperature were fully present, within the maximum limits established by the resolutions CONAMA n ${ }^{\circ} 357 / 2005$ and CONAMA n ${ }^{\circ} 430 / 2011$.

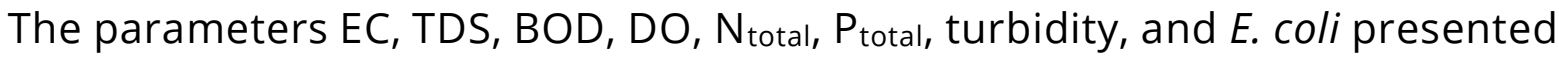
average concentrations higher than those recommended by CONAMA Resolution $n^{\circ} 357 / 2005$, in both dry and rainy seasons, in the mentioned period, however, not all configure the water quality index of Brazilian water bodies.

In the dry season, electrical conductivity was (strongly) positively correlated with chlorides and total phosphorus, and negatively correlated with dissolved oxygen. In the rainy season, electrical conductivity was (highly) positively correlated 
with chlorides and with total nitrogen. Chlorides and total nitrogen were also highly positively correlated.

According to the analysis of the main components, the most relevant parameters that influenced the water quality of the Atibaia river in the dry periods were: electrical conductivity, chlorides, total phosphorus, dissolved oxygen, $\mathrm{pH}$, chemical oxygen demand, turbidity, and temperature. In the rainy periods, the most influential were electrical conductivity, chlorides, total nitrogen, biochemical oxygen demand, chemical oxygen demand, and total dissolved solids.

The quality characteristics related to water mineralization that most influenced the results obtained, both in the dry season and in the rainy season, were $\mathrm{EC}, \mathrm{Cl}^{-}, \mathrm{P}_{\text {total }}$, and $\mathrm{N}_{\text {total }}$, with emphasis on the high levels of $\mathrm{P}_{\text {total }}$ and $\mathrm{N}_{\text {total }}$ that accentuate the problems of eutrophication of a water body.

Thus, given the results achieved, it is considered that the variables $\mathrm{EC}$ and $\mathrm{Cl}^{-}$ should continue to be monitored, since they are variables of remarkable relevance for the detection of contaminants from domestic and/or industrial effluents, and in this study they were the most representative the variability of water quality and can be used as a tool for the management and monitoring of surface water quality.

\section{ACKNOWLEDGEMENTS}

The authors would like to thank the team of the Profa. Dra. Dejanira de Franceschi de Angelis of the Department of Biochemistry and Microbiology at the Institute of Biosciences of the Universidade Estadual Paulista "Júlio de Mesquita Filho" (UNESP), Rio Claro campus for providing the necessary data to conduct the study. This work was carried out with support from the Coordenação de Aperfeiçoamento de Pessoal de Nível Superior - Brasil (CAPES) - Código de Financiamento 001. 


\section{REFERÊNCIAS}

APHA - AMERICAN PUBLIC HEALTH ASSOCIATION. Standard Methods for the Examination of Water and Wastewater. 21. ed. Washington, DC: American Public Health Association. 2005. 1082 p.

BRASIL. Conselho Nacional do Meio Ambiente (CONAMA). Resolução n 357, de 17 de março de 2005. Dispõe sobre a classificação dos corpos de água e diretrizes ambientais para o seu enquadramento, bem como estabelece as condições e padrões de lançamento de efluentes, e dá outras providências.

BRASIL. Conselho Nacional do Meio Ambiente (CONAMA). Resolução $\mathbf{n}^{\circ} \mathbf{4 3 0}$, de 13 de maio de 2011. Dispõe sobre as condições e padrões de lançamento de efluentes, complementa e altera a Resolução n 357, de 17 de março de 2005, do Conselho Nacional do Meio Ambiente CONAMA.

CALLEGARI-JACQUES, S.M. Bioestatística: princípios e aplicações. 1. ed. Porto Alegre, RS: Artmed. 2003. 255 p.

CAMPOS, F.F. Anomalias antrópicas de gadolínio e distribuição dos elementos terras raras nas águas do rio Atibaia e ribeirão Anhumas (SP). 2014. 110 f. Dissertação (Mestrado em Geociências) - Instituto de Geociências, Universidade Estadual de Campinas, Campinas, 2014.

CIIAGRO - Centro Integrado de Informações Agrometeorológicas. Índices pluviométricos. 2018.

DUBUC, A.; WALTHAM, N.; MALERBA, M.; SHEAVES, M. Extreme dissolved oxygen variability in urbanised tropical wetlands: the need for detailed monitoring to protect nursery ground values. Estuarine, Coastal and Shelf Science, v. 198, p. 163-171, 2017.

DURIGON, M.; OLIVEIRA, M. A.; WOLFF, D. B.; CASSOL, A. P. V.; SILVA, J. F. A urbanização compromete a qualidade da água da bacia hidrográfica dos rios Vacacaí e Vacacaí-Mirim em Santa Maria, RS. Ciência e Natura, Santa Maria, v. 37, n. 4, p. 64-73, set-dez. 2015.

EPA - UNITED STATES ENVIRONMENTAL PROTECTIONA AGENCY. Water quality and conditions. 2018.

FINKLER, N. R.; BORTOLIN, T. A.; COCCONI, J.; MENDES, L. A.; SCHNEIDER, V. E. Avaliação espaçotemporal da qualidade da água utilizando técnicas estatísticas multivariadas. Ciência e Natura, Santa Maria, v. 38 n. 2, p. 577-587, mai-ago. 2016.

FRANÇA, M.S. Análise estatística multivariada dos dados de monitoramento de qualidade de água da bacia do Alto Iguaçu: uma ferramenta para a gestão de recursos hídricos. 2009. 166 f. Dissertação (Mestrado em Engenharia) - Universidade Federal do Paraná, Curitiba, 2009. 
GARDIMANJUNIOR, B.S. Caracterização do processo de poluição das águas superficiais da Bacia Hidrográfica do Rio Jucu, estado do Espírito Santo, Brasil. Revista Agro@mbiente On-line, Boa Vista, v. 9, n. 3, p. 235-242, 2015.

GASPAROTTO, F.A. Avaliação ecotoxicológica e microbiológica da água de nascentes urbanas no município de Piracicaba-SP. 2011. 90 f. Dissertação (Mestrado em Ciências), Universidade de São Paulo, Piracicaba, 2011.

GONÇALVES, N.M. PCH Atibaia: o contexto de reativação e a ocorrência de enchentes e inundações no município de Atibaia/SP. 2015. 150 f. Dissertação (Mestrado em Planejamento de Sistemas Energéticos) - Universidade Estadual de Campinas, Campinas, 2015.

GOOGLE MAPS. Ponto de amostragem no rio Atibaia. 2019.

HONGYU, K.; SANDANIELO, V.L.M.; OLIVEIRA JUNIOR, G.J. Análise de componentes principais: resumo teórico, aplicação e interpretação. Engineering and Science, v. 5, n. 1, p. 83-90, 2016.

KIMURA, S.P.R. Determinação química e biológica de carga poluente em lagoa do município de Parintins no estado do Amazonas. 2014. 164 f. Tese (Doutorado em Engenharia Química) - Universidade Estadual de Campinas, Campinas, 2014.

LEITE, D. A. N. O.; RAMOS, M. A. G.; GODÓI, D. R.; MARIANO, A. P.; PIÃO, A. C. S.; ANGELIS, D. F. Avaliação dos parâmetros do índice de qualidade de água segundo o modelo estatístico ARIMA. Holos Environment, v. 13, n. 1, p. 24-39, 2013.

LOCATELLI, M.A.F. Avaliação da presença de antibióticos e drogas ilícitas na bacia do rio Atibaia. 2011. 191 f. Tese (Doutorado em Química Analítica) - Universidade Estadual de Campinas, Campinas, 2011.

MAIA, K.P.; SILVA, G.A.; LIBÂNIO, M. Aplicação de análise multivariada no estudo da frequência de amostragem e do número de estações de monitoramento de qualidade da água. Engenharia Sanitária e Ambiental, Rio de Janeiro, v. 24, n. 5, p. 1013-1025, 2019.

MARCONE, G.P.S. Implementação de ponderação baseada em IQAs na análise exploratória (HCA e PCA) para estudos de qualidade de água. 2006. 61 f. Dissertação (Mestrado em Química) - Universidade Federal da Paraíba, João Pessoa, 2006.

NULL, S.E.; MOUZON, N.R.; ELMORE, L.R. Dissolved oxygen, stream temperature, and fish habitat response to environmental water purchases. Journal of Environmental Management, v. 197, p. 559-570, 2017.

OLIVEIRA, J.G.B. Reator de leito estruturado com aeração intermitente para tratamento combinado de esgoto sanitário e pós tratamento de efluente de Ralf. 2016. $69 \mathrm{f}$. Dissertação (Mestrado em Ciências e Tecnologia de Alimentos) - Universidade Estadual de Ponta Grossa, Ponta Grossa, 2016. 
PIRATOBA, A. R. A.; RIBEIRO, H. M. C.; MORALES, G. P.; GONÇALVES, W. G. Caracterização de parâmetros de qualidade da água na área portuária de Barcarena, PA, Brasil. Revista Ambiente \& Água, Taubaté, v. 12, n. 3, p. 435-456, 2017.

RAMOS, M. A. G.; OLIVEIRA, E. S. B.; PIÃO, A. C. S.; LEITE, D. A. N. O.; ANGELIS, D. F. Water Quality Index (WQI) of Jaguari and Atibaia rivers in the region of Paulínia, São Paulo, Brazil. Environmental Monitoring and Assessment, v. 188, n. 5, p. 263, 2016.

RIBEIRO, G.M.; MAIA, C.E.; MEDEIROS, J.F. Uso da regressão linear para estimativa da relação entre a condutividade elétrica e a composição iônica da água de irrigação. Revista Brasileira de Engenharia Agrícola e Ambiental, Campina Grande, v. 9, n. 1, p. 15-22, 2005.

SILVA JÚNIOR, O.P.; CARVALHO, S.L.; AMÉRICO-PINHEIRO, J.H.P. Avaliação das concentrações de nitrogênio e fósforo na água do córrego das Marrecas, município de Dracena - SP. Revista Científica ANAP Brasil, v. 10, n. 19, 2017.

TAOUFIK, G.; KHOUNI, I.; GHRABI, A. Assessment of physico-chemical and microbiological surface water quality using multivariate statistical techniques: a case study of the Wadi El-Bey River, Tunisia. Arabian Journal of Geosciences, v. 10, p. 181, 2017.

VASCONCELOS SEGUNDO, E.H.; FROEHNER, S.J. Modelo condutométrico para determinação da concentração de dióxido de carbono dissolvido no Reservatório Vossoroca, Brasil. Engenharia Sanitária e Ambiental, Rio de Janeiro, v. 21, n. 3, p. 479-487, 2016.

\section{CONTRIBUIÇÃO DOS AUTORES}

\section{1 - Camila Pereira Montovani}

Doutora em Tecnologia (Ambiente), Universidade Estadual de Campinas https://orcid.org/0000-0003-0235-4657 - camilamontovani@gmail.com

Contribuição: writing - original draft, formal analysis

\section{2 - Cassiana Maria Reganhan Coneglian}

Doutora em Ciências Biológicas (Microbiologia Aplicada), Universidade Estadual Paulista Júlio de Mesquita Filho https://orcid.org/0000-0002-2144-1716 - cassianac@ft.unicamp.br Contribuição: project administration, writing - review \& editing

\section{3 - Elaine Cristina Catapani Poletti}

Doutora em Engenharia Elétrica, Universidade Estadual de Campinas https://orcid.org/0000-0003-4513-0565 elainec@unicamp.br Contribuição: project administration, writing - review \& editing 


\section{How to quote this article}

MONTOVANI, C.P.; CONEGLIAN, C.M.R.; POLETTI, E.C.C. Water quality of the Atibaia river in the city of Paulínia/SP: evaluation of the Electrical Conductivity and Chloride variables. Santa Maria, v. 43, e66, p. 1-21, 2021. Available at: https://doi.org/10.5902/2179460X64748. 